\title{
Copper-Tin Anodes for Rechargeable Lithium Batteries: An Example of the Matrix Effect in an Intermetallic System
}

by

K. D. Kepler, J. T. Vaughey, and M. M. Thackeray
Electrochemical Technology Program
Chemical Technology Division
Argonne National Laboratory
Argonne, $\Pi$ U.S.A.

The submitted manuscript has been created by the University of Chicago as Operator of Argonne National Laboratory ("Argonne") under Contract No. W-31-109-ENG-38 with the U.S. Department of Energy. The U.S. Government retains for itself, and others acting on its behalf, a paid-up, nonexclusive, irrevocable worldwide license in said article to reproduce, prepare derivative works, distribute copies to the public, and perform publicly and display publicly, by or on behalf of the Government.

July 1998

To be presented at the 9th International Meeting on Lithium Batteries, Edinburgh, Scotland, United Kingdom, July 12-17, 1998 


\section{DISCLAIMER}

This report was prepared as an account of work sponsored by an agency of the United States Government. Neither the United States Government nor any agency thereof, nor any of their employees, make any warranty, express or implied, or assumes any legal liability or responsibility for the accuracy, completeness, or usefulness of any information, apparatus, product, or process disclosed, or represents that its use would not infringe privately owned rights. Reference herein to any specific commercial product, process, or service by trade name, trademark, manufacturer, or otherwise does not necessarily constitute or imply its endorsement, recommendation, or favoring by the United States Government or any agency thereof. The views and opinions of authors expressed herein do not necessarily state or reflect those of the United States Government or any agency thereof. 


\section{DISCLAIMER}

Portions of this document may be illegible in electronic image products. Images are produced from the best available original document. 


\title{
Copper-Tin Anodes for Rechargeable Lithium Batteries: An Example of the Matrix Effect in an Intermetallic System
}

\author{
K. D. Kepler, J. T. Vaughey, and M. M. Thackeray* \\ Electrochemical Technology Program \\ Chemical Technology Program \\ Argonne National Laboratory \\ Argonne IL 60439
}

Keywords: lithium battery, anode, intermetallic, tin alloy

\begin{abstract}
Lithium batteries are typically constructed from a lithium cobalt oxide cathode and a carbon anode. We have investigated intermetallic anode materials based on tin, which can provide a high capacity at a slightly higher voltage $(400 \mathrm{mV})$ than metallic lithium and thus reduce the safety concerns associated with the carbon anode. In particular, we have investigated the copper-tin system at around the composition $\mathrm{Cu}_{6} \mathrm{Sn}_{5}$ and have determined the effect on cycling and capacity of electrodes with various ratios of copper to tin. Anode compositions that are slightly copper rich $\left(\mathrm{Cu}_{6} \mathrm{Sn}_{4}\right)$ were found to exhibit greater utilization of the tin than those with the stoichiometric bronze ratio $\left(\mathrm{Cu}_{6} \mathrm{Sn}_{5}\right)$ or those having a slight excess of tin $\left(\mathrm{Cu}_{6} \mathrm{Sn}_{6}\right)$. The differences in electrochemical behavior are explained in terms of an inert matrix model.
\end{abstract}

* Corresponding author, email: thackeray@cmt.anl.gov: Tele: (630)-252-9184; Fax: (630)-252-4176 


\section{Introduction}

Lithium batteries represent an important area of study and a developing market for commercial battery companies. Conventional lithium-ion cells are constructed from a lithium cobalt oxide cathode and a carbon anode. When graphite is used, this electrochemical couple provides a voltage of approximately $4 \mathrm{~V}$. There is some concern about the cost of the cathode, irreversible capacity losses with cycling and safety of the anode [1]. We have been searching for alternative anode materials to carbon and have been investigating intermetallic materials based on tin which provide a high capacity at a slightly higher voltage $(400 \mathrm{mV})$ than metallic lithium, thus reducing safety concerns.

It is known that although the capacity of pure tin is high (990 $\mathrm{mAh} / \mathrm{g})$, it has a limited cycle life. This has been attributed to a number of causes, including electronic isolation of the lithiated product and poor electrical contact with the current collector caused by the frequent expansion/compression cycles associated with the lithiation [2]. It has been suggested that isolating the tin within a host matrix would solve many of these problems [2]. One of the more recently publicized methods was reported by Fujifilm Celltec. They successfully loaded tin oxide ( $\mathrm{SnO}$ ) into a porous borophosphate glass, and were able to demonstrate high capacity and low fade with cycling [3]. Later reports by Courtney and Dahn [4] indicated that the reaction mechanism involved the decomposition of the tin oxide to tin metal and a subsequent alloying reaction with lithium. Although under certain conditions the tin oxide was shown to be a stable anode system, problems with an initial large irreversible capacity have limited its effectiveness. An alternative to the oxide precursor is to use a tin intermetallic compound that does not require the reduction of tin oxide (producing irreversible capacity). We have chosen to investigate intermetallic compounds in the copper tin system because they are easy to synthesize, stable in an air environment, and because structural decomposition would encase the lithium/tin alloy in a conductive copper matrix. Here, we report our work on alloy compositions at and around the $\varepsilon$-bronze $\mathrm{Cu}_{6} \mathrm{Sn}_{5}$. 


\section{Experimental}

Three compositions were synthesized in the copper-tin system: $\mathrm{Cu}_{6} \mathrm{Sn}_{5}, \mathrm{Cu}_{6} \mathrm{Sn}_{4}$, and $\mathrm{Cu}_{6} \mathrm{Sn}_{6}$. The copper tin intermetallics were synthesized by direct reaction of the elements. Elemental copper (Johnson Mathey 99.9\%) and tin (Aldrich, 99.8\%) powder were mixed in a stoichiometric ratio to yield the desired product. The mixed powders were then pressed into a pellet, placed into an alumina crucible, and heated under an argon atmosphere at $400{ }^{\circ} \mathrm{C}$ for $12 \mathrm{hr}$. The gray brittle product was then ground and sifted to approximately 400 mesh. X-ray diffraction analysis of the product gave the expected product distribution in each case. The stoichiometric bronze $\mathrm{Cu}_{6} \mathrm{Sn}_{5}$ was a single phase, the composition $\mathrm{Cu}_{6} \mathrm{Sn}_{4}$ gave a mixture of copper and the bronze, while the composition $\mathrm{Cu}_{6} \mathrm{Sn}_{6}$ gave the bronze plus tin.

Additionally, we synthesized the lithium-copper-tin Zintl phase, $\mathrm{Li}_{2} \mathrm{CuSn}$ ( $\mathrm{MnCu}_{2} \mathrm{Al}$-type), as a lithiated precursor to $\mathrm{Cu}_{6} \mathrm{Sn}_{5}$. Elemental lithium, copper, and tin were weighed out in stoichiometric amounts and placed in a tantalum tube, one end of which had been crimped shut to form a metal test tube. The sample was heated to $900^{\circ} \mathrm{C}$ under an argon atmosphere, held for three hours, and cooled radiatively to room temperature. The violet-purple sample was then isolated from the tube as a powder. Xray analysis of the sample confirmed the isolation of the desired phase [5].

Laminates of the alloy materials and pure tin were evaluated in 1225 coin cells vs. $\mathrm{Li}$ metal. The electrolyte used was $1 \mathrm{M} \mathrm{LiPF}_{6}$ in ethylene carbonate/diethyl carbonate (50:50). The positive electrode laminates were made by doctor blading slurries containing approximately $6 \mathrm{mg}$ of active copper-tin material ( $81 \%$ by mass), mixed with carbon (XC-72, $9 \%$ by mass) and binder (Kynar $2801,10 \%$ by mass) in tetrahydrofuran (THF). The air-sensitive $\mathrm{Li}_{2} \mathrm{CuSn}$ laminates were made in a glove box. Cell construction is described elsewhere [6]. Cells were discharged and charged at constant current $(0.1$ $\mathrm{mA}$ ) between either 1.2 and $0.0 \mathrm{~V}$, or 1.2 and $0.2 \mathrm{~V}$.

\section{Results and Discussion}

The idea of using an inert matrix to shield a battery anode was proposed by Huggins a number of years ago [2]. We have investigated the use of intermetallic alloys 
as anodes, termed $M^{\prime} M$, where $M^{\prime}$ is an inactive metal and $M$ is the component that alloys with lithium. In this paper, the specific intermetallic we have chosen to concentrate on is the $\varepsilon$-bronze compound $\mathrm{Cu}_{6} \mathrm{Sn}_{5}$. Lithium insertion directly into this compound is not possible because it lacks an interstitial site for the extra cation and has a closed electronic configuration. The structure is shown in Fig. 1. Thus, any reaction with lithium must happen by a displacement reaction and a breakdown of the starting bronze compound to form copper (the inactive component) and tin. Further lithiation of the system forms a series of lithium tin alloys $\left(\mathrm{Li}_{\mathrm{x}} \mathrm{Sn}, 0<\mathrm{x} \leq 4.4\right)$ that follows the known phase diagram. It is this tin that provides the anode capacity, while the displaced copper, dispersed into the solid, acts as an electronically conducting matrix. It is envisioned that this matrix will mitigate some of the unwanted expansion and contraction observed in lithium alloy systems.

In our experiments, the three samples synthesized had the composition $\mathrm{Cu}_{6} \mathrm{Sn}_{5+\delta}$ $(\delta=0, \pm 1)$. The sample with $\delta=0$ is the single-phase bronze, the sample with $\delta=1$ has excess tin in the starting material, and the sample with $\delta=-1$ has an excess of copper. Fig. 2(a and b) shows the voltage profile for $\mathrm{Li} / \mathrm{Sn}$ and $\mathrm{Li} / \mathrm{Cu}_{6} \mathrm{Sn}_{5}$ cells. All cells with $\mathrm{Cu}-\mathrm{Sn}$ anodes had profiles similar to pure tin and exhibited a distinct voltage plateau around $400 \mathrm{mV}$ versus lithium, corresponding in the phase diagram to $\mathrm{Li}_{7} \mathrm{Sn}_{3}$. All of the $\mathrm{Cu}-\mathrm{Sn}$ cells cycled better than our pure tin cells prepared in the same manner (Fig. 3). Interestingly, we found that the greater the amount of $\mathrm{Cu}$ in the alloy, the better the utilization of the tin. Thus, $\mathrm{Cu}_{6} \mathrm{Sn}_{4}$ exhibited the highest capacity per mass of tin present (Fig. 4). We believe that this effect is related to the microstructure produced during the initial decomposition of the alloy, which should lead to finely divided tin in an inactive copper matrix. The additional $\mathrm{Cu}$ might lead to more finely divided tin, and the high surface area of the tin could be accessible to $\mathrm{Li}$ through grain boundary diffusion. The capacity fade of the $\mathrm{Cu}$-Sn materials was slightly less than that of pure tin, suggesting that the presence of a $\mathrm{Cu}$ matrix has only partially decreased the swelling problems. The addition of more $\mathrm{Cu}$ might help the cycle life but at the expense of cell capacity. The capacity retention was improved by changing the lower voltage cutoff to $200 \mathrm{mV}$, though with a loss of cell capacity (Fig. 5). 
We also investigated the lithium copper tin Zintl phase, $\mathrm{Li}_{2} \mathrm{CuSn}$, shown schematically in Fig. 6. For this compound, besides the initial delithiation, the cycling profile is similar to that observed for $\mathrm{Cu}_{6} \mathrm{Sn}_{5}$ (Fig. 2c). Interestingly, the delithiation of $\mathrm{Li}_{2} \mathrm{CuSn}$ at $\sim 800 \mathrm{mV}$ is $400 \mathrm{mV}$ greater than the potential for the delithiation of $\mathrm{Li}_{7} \mathrm{Sn}_{3}$, the $\mathrm{Li}-\mathrm{Sn}$ phase with the closest lithium to tin ratio. This suggests that the addition of $\mathrm{Cu}$ to the metal framework stabilizes the $\mathrm{Sn}$ to oxidation. In the $\mathrm{Li}_{2} \mathrm{CuSn}$ cells, the cell capacity was well below the expected value of $\sim 650 \mathrm{mAh} / \mathrm{g}$ (Fig. 3), which we partly ascribe to the electrical isolation of a large portion of the material during processing as the compound reacted with air to form $\mathrm{Li}_{2} \mathrm{O}$ and "Cu-Sn". Overpotential problems caused by this effect could also explain the initial low discharge plateau $(\sim 200 \mathrm{mV})$ of some of the $\mathrm{Li}_{2} \mathrm{CuSn}$ cells. It appears that the delithiation process produces a mix of finely divided tin, and the bronze $\mathrm{Cu}_{6} \mathrm{Sn}_{5}$ then proceeds along the reaction pathway stated above. For all of these $\mathrm{Cu}-\mathrm{Sn}$ materials, it appears that the initial lithiation of the alloy results in the decomposition of the material to form a matrix of active $\mathrm{Sn}$ in inactive $\mathrm{Cu}$.

\section{Conclusions}

Copper-tin intermetallic materials have been investigated as anode materials to replace carbon in lithium-ion cells. This initial study has demonstrated the strong effect that an inactive matrix element can have on the utilization of the active Sn component. Some improvement in the cycling of these materials over pure tin was also observed.

\section{Acknowledgment}

Support from the Advanced Battery Program, Chemical Sciences Division, Office of Basic Energy Sciences, US Department of Energy under contract no. W-31-109-Eng38 is gratefully acknowledged.

\section{References}

1. G. Pistoia, Lithium Batteries, New Materials, Developments, and Perspectives, Industrial Chemistry Library, Vol. 5, Elsevier, Amsterdam (1994).

2. J. Wang, I. D. Raistrick, and R. A. Huggins, J. Electrochem. Soc. 133, 457 (1986). 
3. Y. Idota, T. Kubota, A. Matsufuji, Y. Maekawa, and T. Miyasaka, Science 276, 1395 (1997).

4. I. A. Courtney and J. Dahn, J. Electrochem. Soc. 144, 2045 (1997).

5. V. V. Pavlyuk, O.I. Bodak, and G. S. Dmytriv, Ukr. Khim. Zh. 58, 735 (1992).

6. C. S. Johnson, D. W. Dees, M. F. Mansuetto, M. M. Thackeray, D. R. Vissers, D. Argyriou, C.-K. Loong and L. Christensen, J. Power Sources, 68, 570 (1997). 


\section{Captions to Figures}

Fig. 1. The structure of $\mathrm{Cu}_{6} \mathrm{Sn}_{5}$. The black spheres represent the trigonal prismatic coordination of the tin site, while the gray spheres represent the copper, which has octahedral coordination.

Fig. 2. The electrochemical profiles of the first discharge and subsequent charge of a typical (a) $\mathrm{Li} / \mathrm{Sn}$ cell, and (b) $\mathrm{Li} / \mathrm{Cu}_{6} \mathrm{Sn}_{5}$ cell, and (c) the charge and subsequent discharge of a typical $\mathrm{Li} / \mathrm{Li}_{2} \mathrm{CuSn}$ cell.

Fig. 3. Capacity vs. cycle number for $\mathrm{Li} / \mathrm{Sn}, \mathrm{Li}_{2} \mathrm{CuSn}$, and $\mathrm{Li} / \mathrm{Cu}_{6} \mathrm{Sn}_{5+_{\delta}}(\delta=0, \pm 1)$ cells over the range $1.2-0.0 \mathrm{~V}$ ( 20 cycles).

Fig. 4. Cell capacity in $\mathrm{mAh} /(\mathrm{g} \mathrm{Sn})$ vs. cycle number for $\mathrm{Li} / \mathrm{Sn}$ and $\mathrm{Li} / \mathrm{Cu}_{6} \mathrm{Sn}_{5+\delta}(\delta=0, \pm 1)$ cells cycled over the range 1.2 to $0.0 \mathrm{~V}$ ( 20 cycles).

Fig. 5. Cell capacity vs. cycle number for $\mathrm{Li} / \mathrm{Sn}$ and $\mathrm{Li} / \mathrm{Cu}_{6} \mathrm{Sn}_{5_{\delta}}(\delta=0, \pm 1)$ cells cycled over the range 1.2 to $0.2 \mathrm{~V}$ ( 20 cycles).

Fig. 6. The structure of $\mathrm{Li}_{2} \mathrm{CuSn}$. In this material, lithium cations occupy the interstitial sites created within a copper (gray spheres) and tin (black spheres) metal array. 


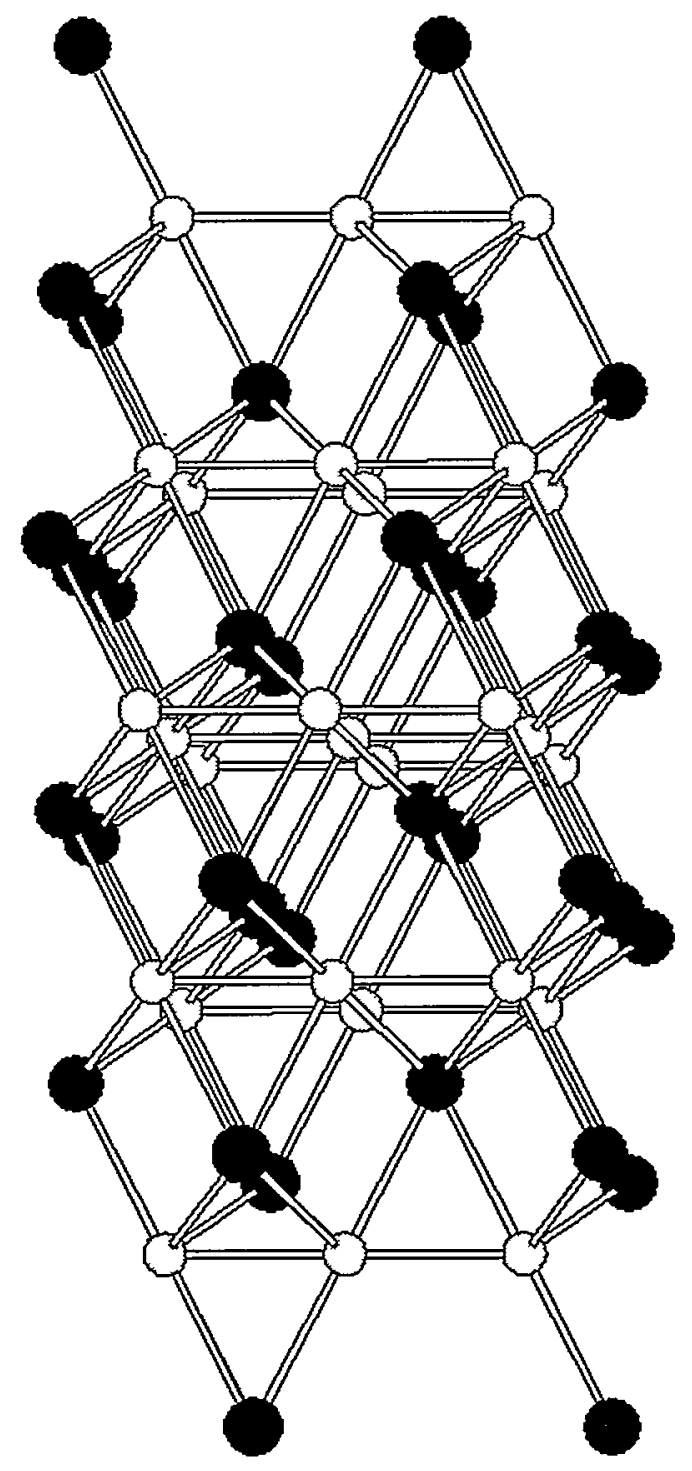

$\stackrel{-\infty}{\dot{0}}$ 
Fig. 2a

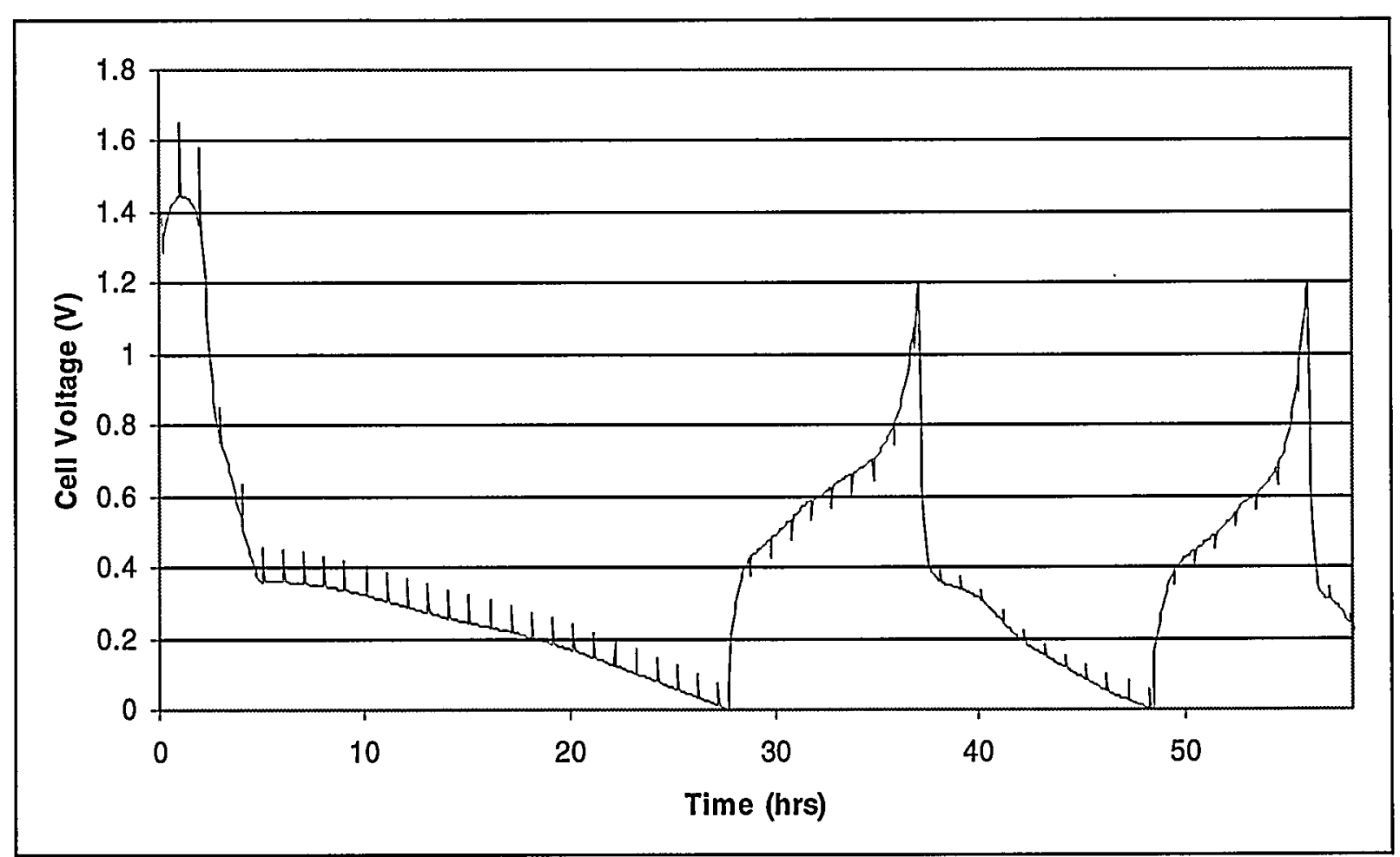


Fig. 2b

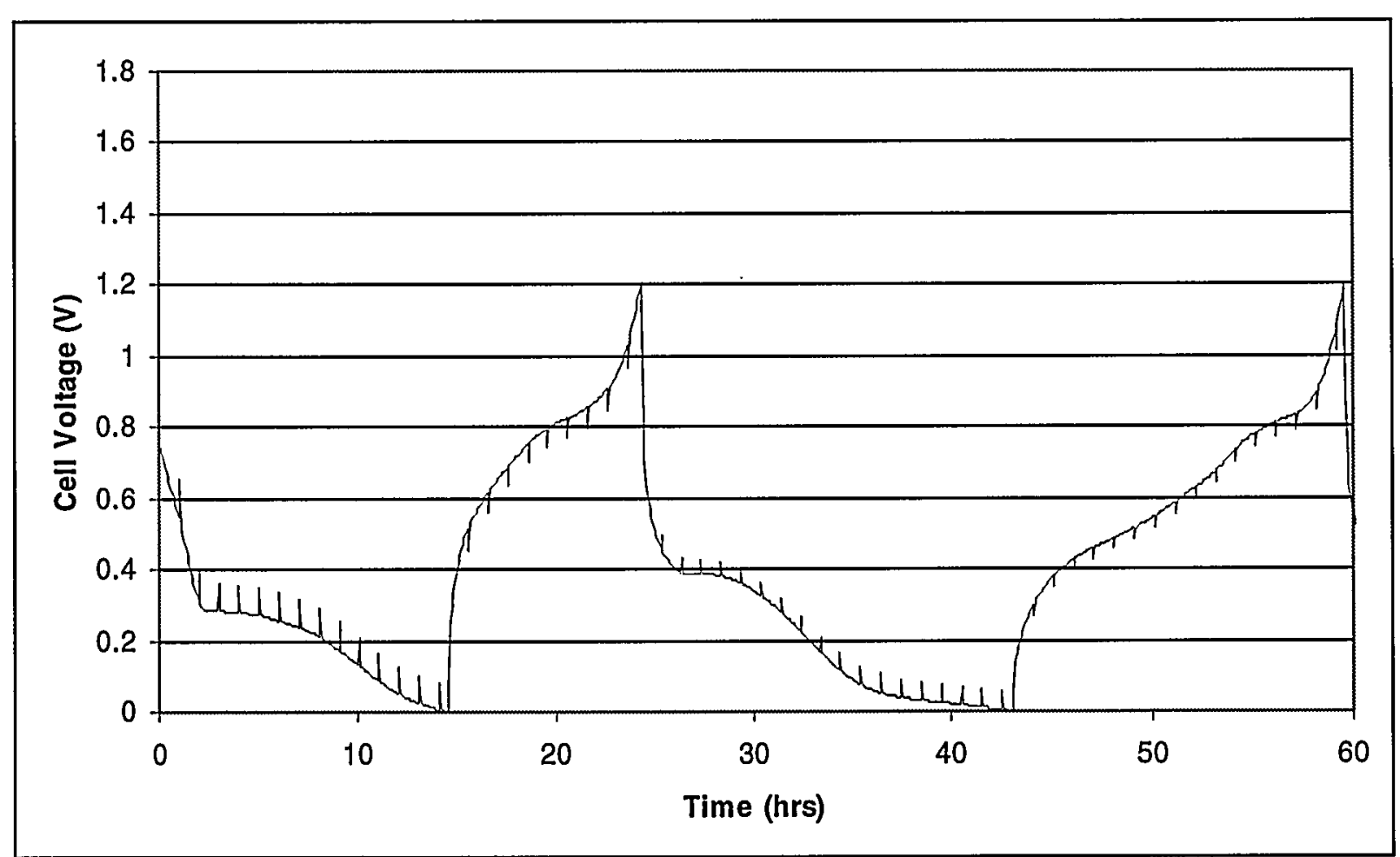


Fig. 2c

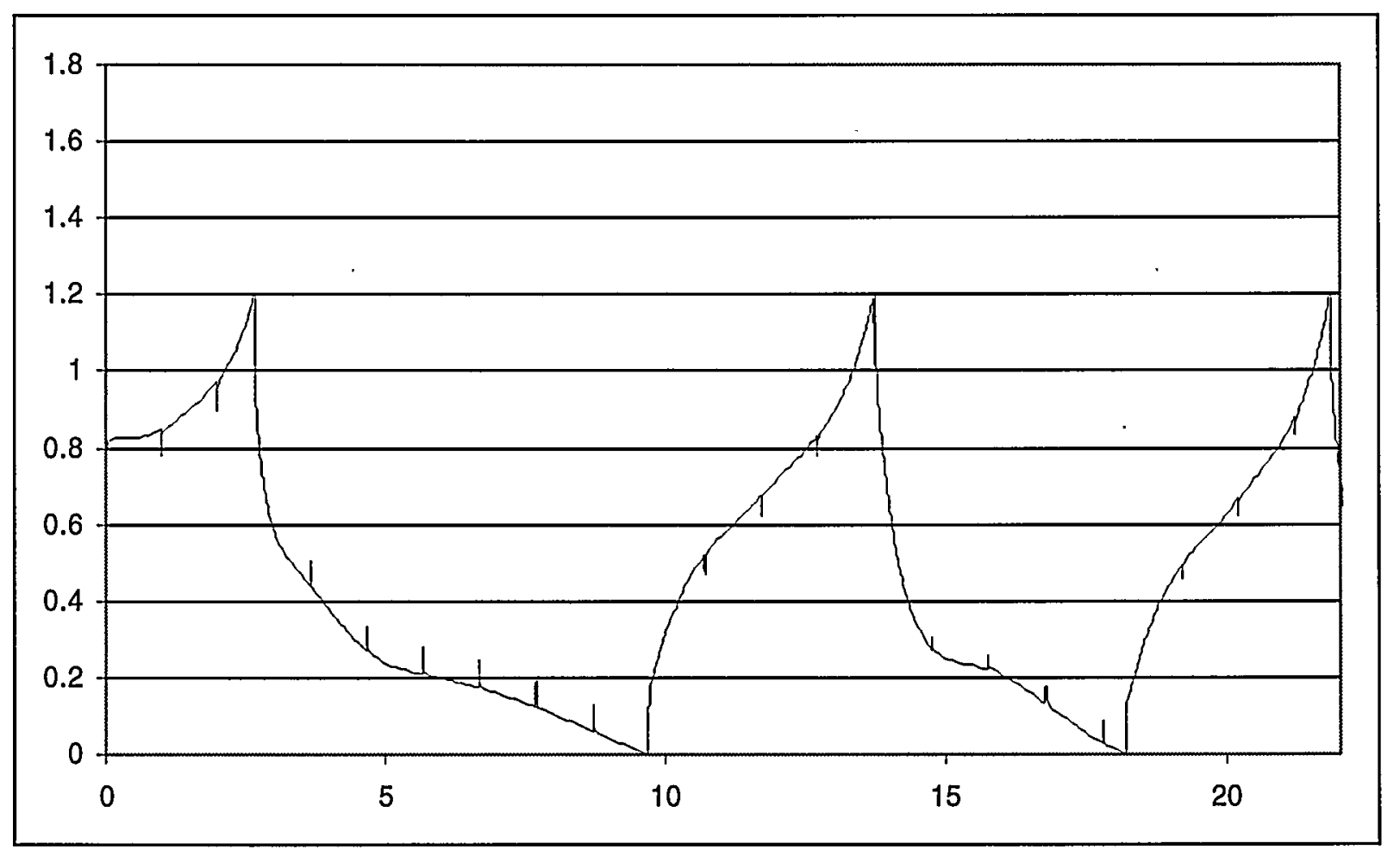


Fig. 3

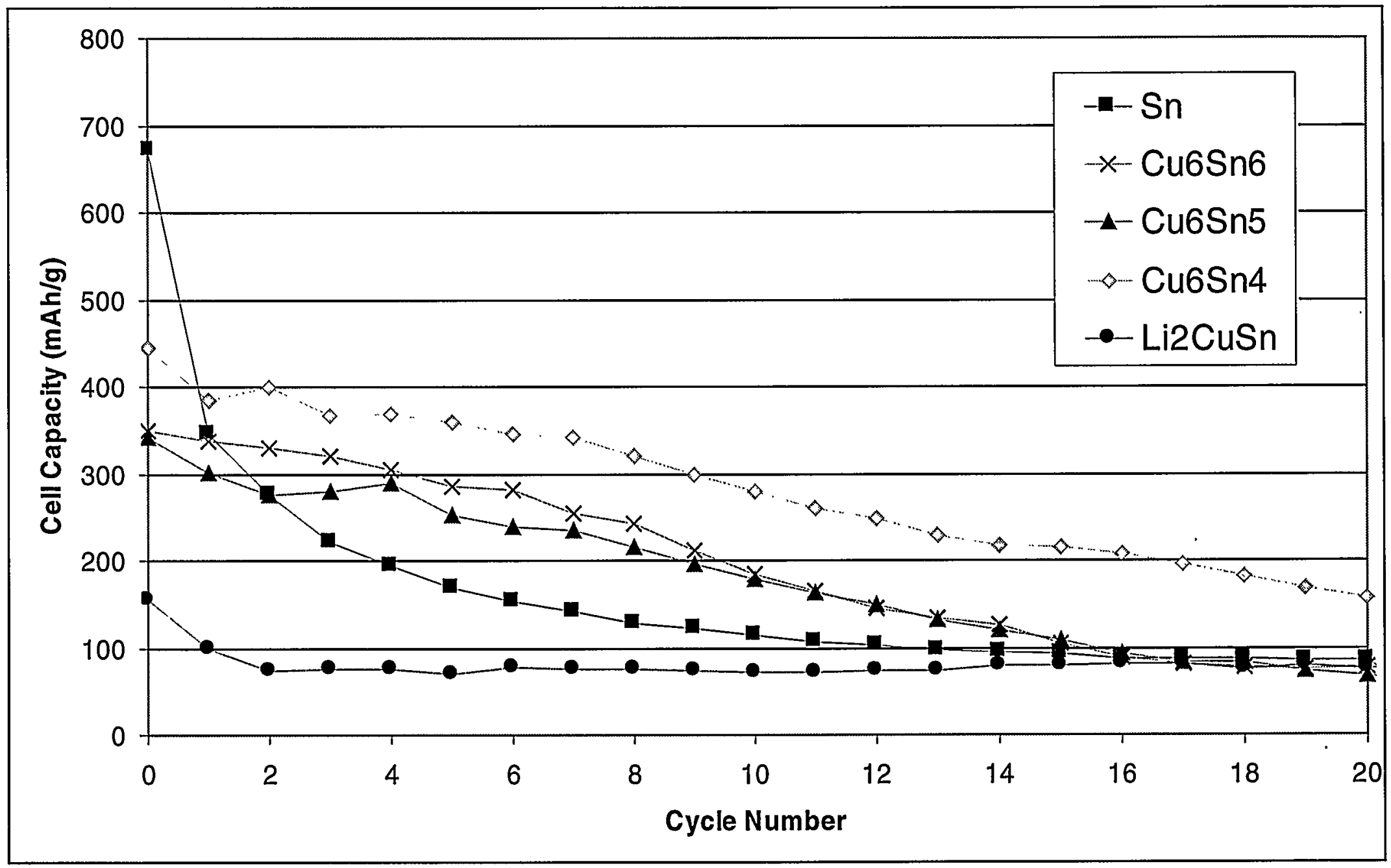


Fig. 4

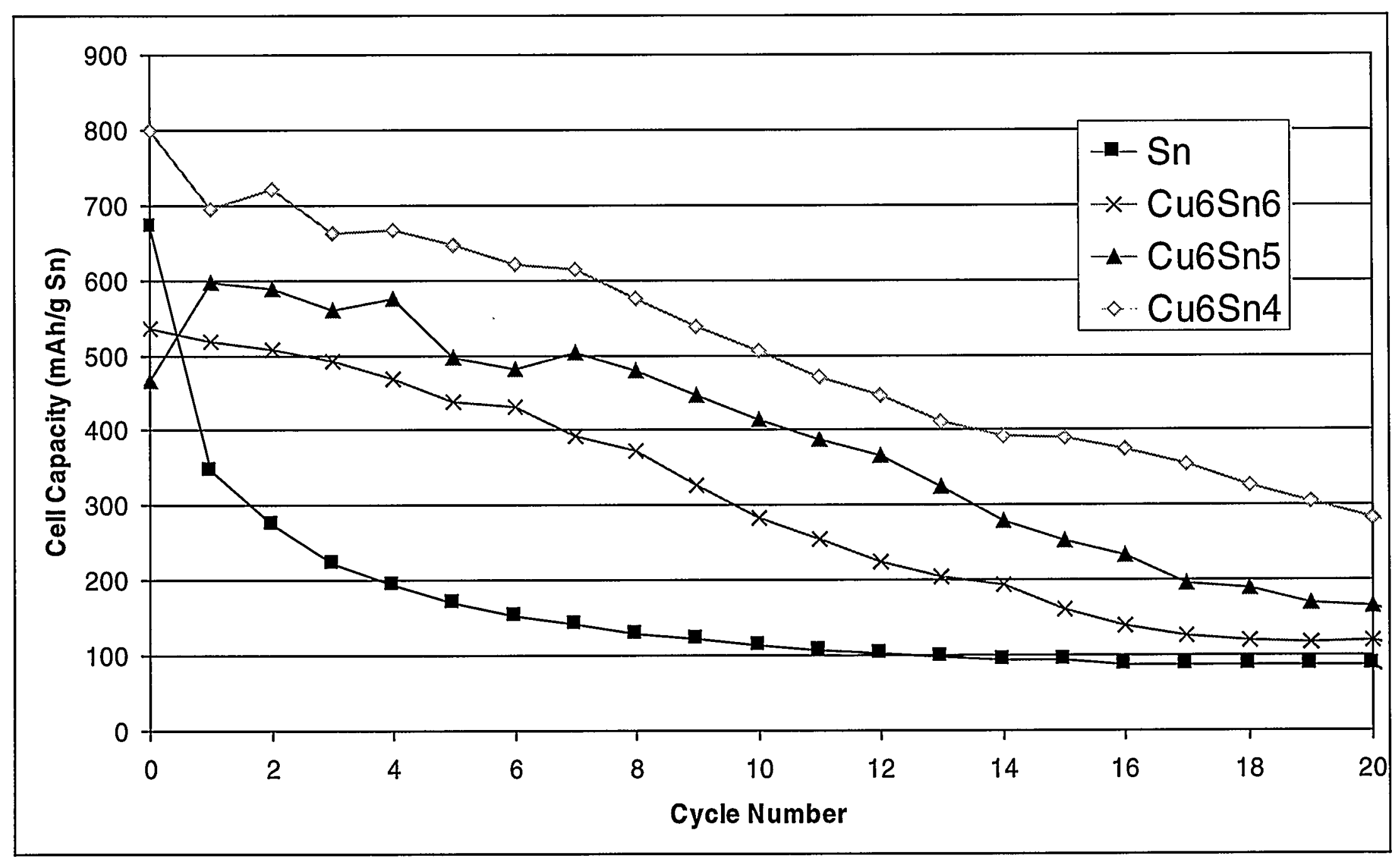




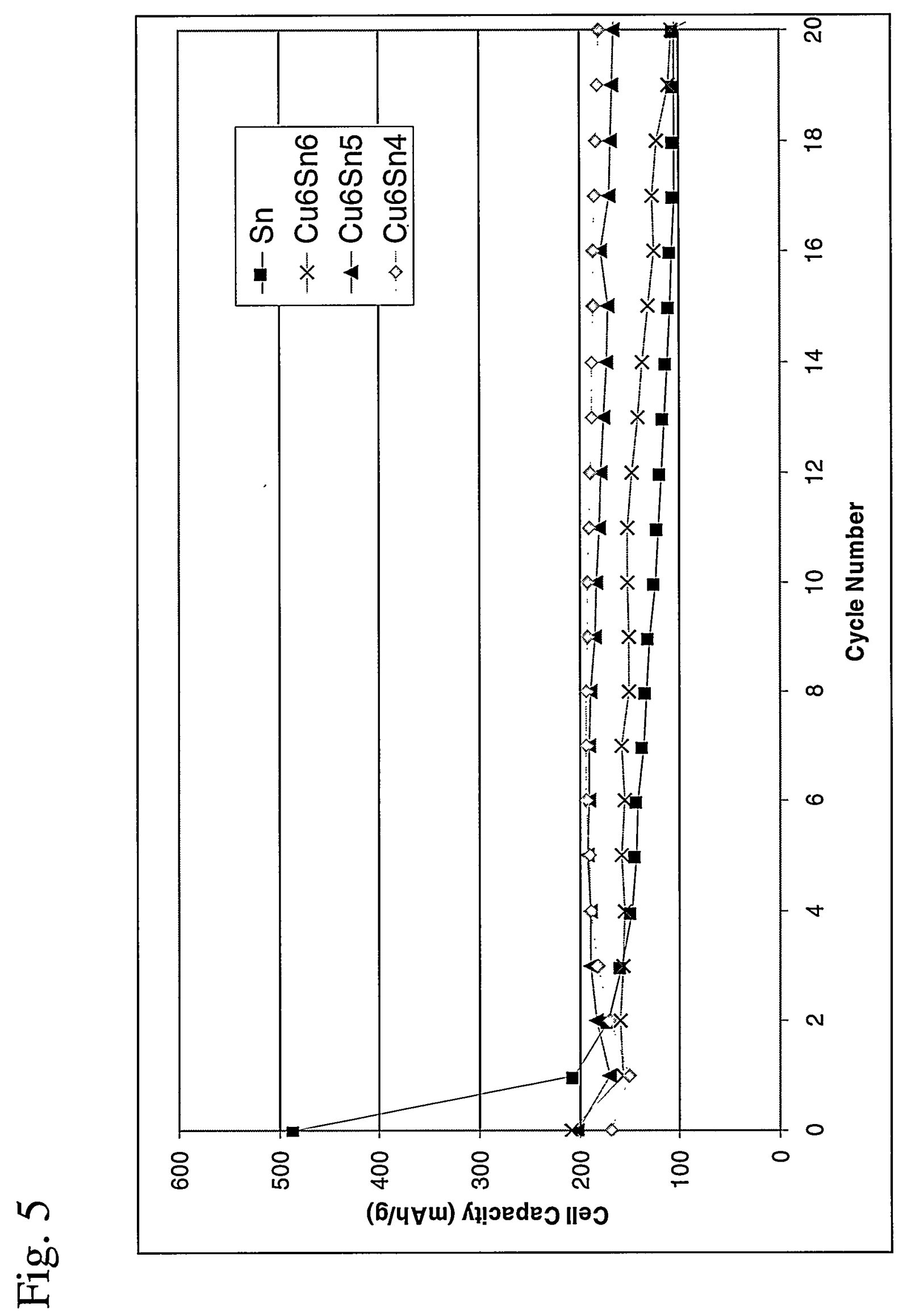




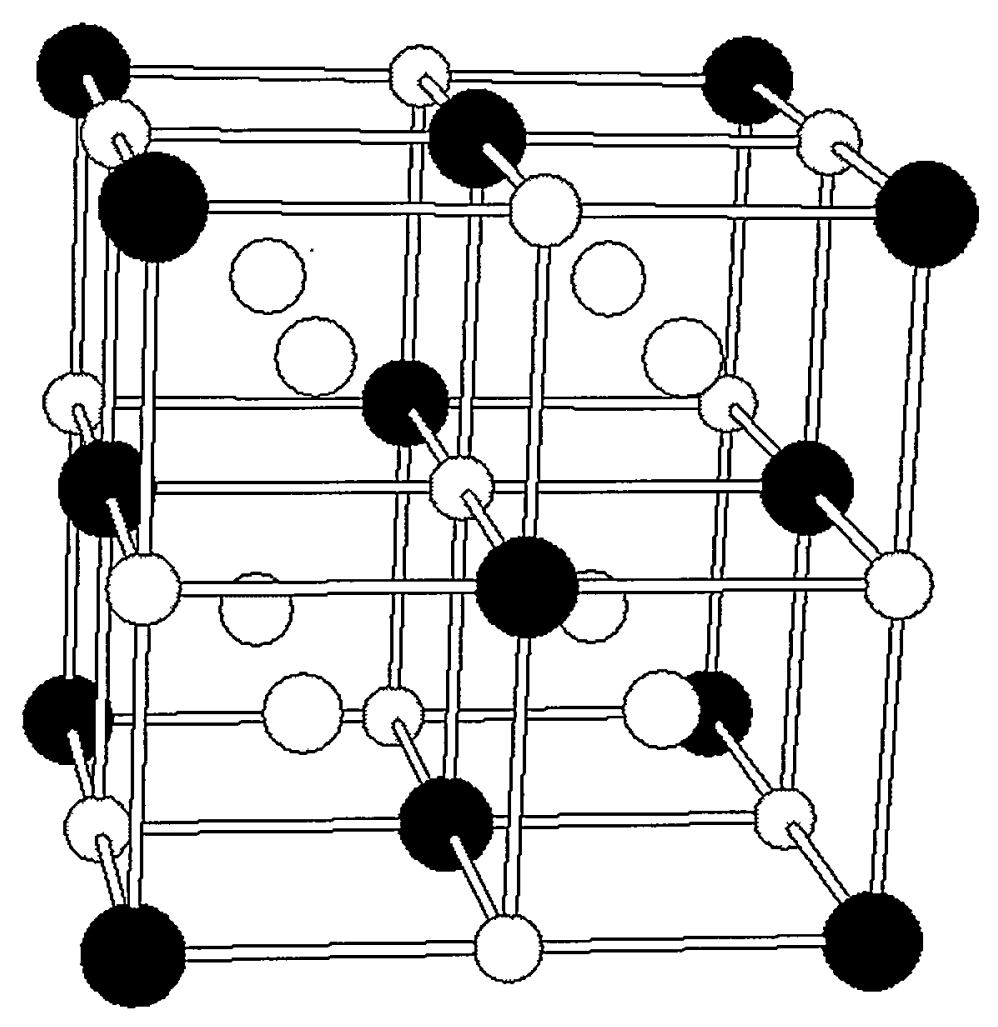

6
$\dot{00}$ 